neofilolog

Czasopismo Polskiego Towarzystwa Neofilologicznego

ISSN 1429-2173, 2019, NR 53/2, 213-226

http://dx.doi.org/10.14746/n.2019.53.2.5

http://poltowneo.org/

Katarzyna Nosidak

Uniwersytet Pedagogiczny im. Komisji Edukacji Narodowej w Krakowie https://orcid.org/0000-0001-8315-2525 katarzyna.nosidlak@up.krakow.pl

\title{
CZYNNIKI OSOBOWOŚCIOWE W PROCESIE PRZYSWAJANIA I UŻYCIA JĘZYKA OBCEGO - KWESTIA EWALUACJI WYPOWIEDZI USTNEJ
}

\section{Personality related factors in the process of foreign language acquisition and use - evaluation of students' oral performance}

Communication in a foreign language requires activation of numerous, not necessarily linguistic, competences. As recent studies suggest, in order to facilitate this complicated process, people tend to put on different masks and change their personality-related behaviours. Such behavioural changes seem to be typical for testing situations when students' actions are additionally influenced by stress. Drawing on her own observations and teaching experience, the author of this article strives to point to the correspondence between the manifestation of some behaviours resulting from students' personality makeups and the effectiveness of their spoken performance in a foreign language. By directing readers' attention to this correlation, she wants to underline the importance of personality training for the sake of effective communication in a foreign language. Additionally, this article presents the results of a survey conducted among 54 students of English at the Pedagogical University of Cracow - the data collected shows that students intentionally alter their personality-related behaviours in an attempt to earn higher scores on their oral exams. The direction of these changesmight constitute useful advice for less experienced foreign-language test-takers.

Keywords: evaluation of oral performance, individual learner differences, personality, personality states, personality training

Słowa kluczowe: ocena wypowiedzi ustnej, osobowość, różnice indywidualne, stany osobowościowe, trening osobowościowy 


\section{Wstęp}

Jak pokazują liczne badania, osobow ość jednostki ma istotne znaczenie na przebieg procesu opanowywania jezzyka obcego (por. m.in. Lalonde i in., 1987; Biedroń, 2011; Studenska, 2011). Ponadto obserwuje się równiez wpływ tej zmiennej indywidualnej na jakość i poziom wypowiedzi ustnych w języku obcym (por. Liang i Kelsen, 2018). Rozpatrując zaś zagadnienie znaczenia osobowości ucznia w szerszym ujęciu edukacyjnym, należy podkreślić, że czynniki osobowościowe mają w pływ na uzyskiwane wyniki egzaminacyjne, co często przekłada się na dalsze losy edukacyjne czy zawodowe jednostki (Furnham i Chamorro-Premuzic, 2004).

Z uwagi na rozpowszechnione również wśród psychologów i pedagogów przekonanie, że osobowość jednostki kształtuje się w dzieciństwie (DiSaIvo, 2018), a późniejsze zmiany osobowościowe są zazwyczaj wynikiem traumatycznych przeżyć, ocenianie uczniów przez pryzmat ich osobowości budzi wątpliwości natury etycznej. Problem ten jest sygnalizowany m.in. w Europejskim systemie opisu kształcenia językowego (ESOKJ, [2001] 2003), przy okazji omawiania znaczenia tzw. kompetencji ogólnych. Poprzez uwzględnienie czynników osobowościowych w kompetencji ucznia, twórcy ESOKJ zdają się reprezentować stanowisko, iż są one modyfikowalne, a ich rozwój może stanowić cel edukacyjny i w związku z tym podlegać ocenie. W konsekwencji, z tak przyjętym założeniem, promowanie manifestacji pewnych cech osobowości, jak również zachęcanie do kontrolowania innych, staje się kolejnym zadaniem nauczyciela języków obcych.

W swoim artykule autorka, opierając się m.in. na wytycznych zawartych w ESOKJ (2003), stara się odpowiedzieć na pytanie, czy w świetle obecnej wiedzy pedagogicznej i psychologicznej, możliwe jest wykształcenie określonych zachowań pomocnych w komunikacji w języku obcym u osób nieposiadających predyspozycji osobowościowych do takich zachowań. Spróbuje też odpowiedzieć na pytanie, na ile proces ten może zależeć od nauczyciela i czy jego rezultaty mogą podlegać jakiejkolwiek ocenie. Bazując na swoich doświadczeniach w pracy ze studentami filologii angielskiej, autorka pragnie równiez zwrócić uwagę na potencjalny w pływ zachowań wynikających z uwarunkowań osobowościowych jednostek na ocenę ich wypowiedzi ustnych w języku obcym, a także na wpływ sposobu oceniania na zmiany w ich zachowaniu w sytuacji egzaminacyjnej. W artykule zaprezentowano wyniki ankiety, w której studenci filologii angielskiej, doświadczeni w przystępowaniu do różnorakich egzaminów i odnoszący sukcesy w nauce języków obcych, mieli szanse wskazać, które zachowania, związane z określonymi cechami osobowości, uważają za przydatne w osiągnięciu wyższej oceny na egzaminach ustnych. 
Czynniki osobowościowe w procesie przyswajania i użycia języka obcego...

\section{Kompetencje ucznia a jego osobowość}

Jak wielokrotnie podkreśla się w ESOKJ (2003), celem procesu nauczania języka obcego jest wykształcenie w uczniu szeregu różnorodnych kompetencji, które umożliwią mu skuteczną komunikację w języku obcym. Kompetencje użytkownika języka obcego możemy, za ESOKJ (2003: 94-114), podzielić na językowe i pozajęzykowe. Przeglądając programy i podręczniki do nauczania języków obcych, czy też analizując standaryzowane testy językowe, można zauważyć, że w procesie nauczania, to właśnie rozwój kompetencji stricte językowych, takich jak np. kompetencja lingwistyczna czy gramatyczna, jest traktowany priorytetowo. Nie należy jednak zapominać, iż dla skutecznej komunikacji w języku obcym, znaczenie równie kluczowe mają kompetencje pozajęzykowe. Wśród nich wymienia się:

1) umiejętność uczenia się, czyli gotowość do obserwacji nowych zjawisk i uczestnictwa w nowych doświadczeniach, pozwalająca na rozwój osobisty i intelektualny (możemy tu wymienić np. wrażliwość językową i komunikacyjną, czy też znajomość technik uczenia się);

2) wiedzę deklaratywną, czyli wiedzę o świecie, miejscach, instytucjach; świadomość istnienia różnic kulturowych i wiedza na temat społeczności posługującej się językiem docelowym, przy jednoczesnym demonstrowaniu wrażliwości interkulturowej;

3) wiedzę proceduralną, czyli szereg umiejętności pozwalających na funkcjonowanie w społeczeństwie, takich jak umiejętności społeczne, życiowe czy stricte zawodowe, ale również umiejętności interkulturowe;

4) uwarunkowanie osobowościowe, obejmujące postawy, motywację, systemy wartości, poglądy, style poznawcze oraz cechy osobowości jednostki.

Według ESOKJ (2003: 97), czynniki osobowościowe, w tym osobowość, mają wpływ zarówno na efektywność naszych działań komunikacyjnych, jak również na naszą zdolność uczenia się. Autorzy ESOKJ (ibid.) wskazują tu w szczególności na przydatność cech, charakteryzujących tzw. osobowość interkulturowq, która przejawia się zarówno w pewnych postawach, jak i w ogólnie pojętej wrażliwości, której rozwój postrzegany jest często jako cel edukacyjny sam w sobie.

Jak już wspomniano powszechnie zakorzeniło się freudowskie przekonanie, iż osobowość kształtuje się do wczesnych lat młodzieńczych, a późniejsze zmiany w jej obszarze są prawie niemożliwe, choć, jak piszą np. O'Brien, Kennedy i Ballard (2007: 9), późniejsi psychologowie często postrzegają osobowość człowieka jako zmienną i kształtującą się przez całe życie. Zagadnienie świadomego kierowania rozwojem osobowości oraz oceniania zachowań z nią utożsamianych często wzbudza wątpliwości natury etycznej. Tak więc, wymienianie 
pewnych uwarunkowań osobowościowych między kompetencjami, które $z$ definicji są wyuczalne i nabywane wraz z doświadczeniem (por. internetowy Słownik języka polskiego PWN, 2018), wiąże się z koniecznością rozstrzygnięcia kwestii etycznych i pedagogicznych, na które wskazuje się w ESOKJ (2003: 97). Po pierwsze, należy rozważyć, jak daleko rozwijanie osobow ości uczącego się może stanowić wyraźny cel edukacyjny - z osiągnięcia celów uczniowie są przecież rozliczani. Po drugie, problemem wydaje się próba łączenia relatywizmu kulturowego z integralnością etyczną i moralną jednostek. Po trzecie, należy również być świadomym, które czynniki osobowościowe ułatwiają, a które utrudniają uczenie się, przyswajanie oraz użycie języka obcego lub drugiego. Zagadnienie to można rozpatrywać, zarówno z punktu widzenia badań nad wpływem uwarunkowań indywidualnych jednostki na te procesy (por. podrozdział 3), jak i tych uwzględniających różnice kulturowe w postrzeganiu zachowań, które wynikają z cech osobowości jednostki. Co więcej, różnorodność osobow ości uczniów często kłóci się z ograniczeniami narzucanymi przez systemy edukacyjne, a próby pogodzenia stanowisk często leżą w gestii nauczyciela. Istotna pozostaje także kwestia tzw. treningu osobowościowego ${ }^{1}$. Jego przykładem może być zachęcanie nieśmiałego ucznia do przełamywania własnych barier i prób komunikacji przy użyciu odpowiednich technik, np. pracy w grupach, a nie zabierania głosu na forum całej klasy. Trening osobowościowy wiąże się z umiejętnością wsparcia uczniów w wykorzystywaniu ich atutów i pokonywaniu słabości związanych z ich uwarunkowaniami osobowościowymi, w celu skutecznego komunikowania się w kontekście interkulturowym, do czego zachęca się w ESOKJ (2003: 97).

Reasumując, użytkownicy ESOKJ (2003: 98) zachęcani są do refleksji nad potrzebą rozwijania określonych cech osobowości u uczących się, nad kwestią ich manifestacji w określonych sytuacjach, w tym również egzaminacyjnych, a także nad ich wpływem na proces uczenia się, nauczania i oceniania. Częściowo podpowiedzi dotyczące tych kwestii kryją się w samym ESOKJ, gdzie możemy przeczytać, że najważniejszym celem edukacji językowej jest wspieranie osobowości uczącego się, jego poczucia tożsamości przez doświadczanie bogactwa innych języków i kultur. Zadaniem nauczycieli i samych uczących się pozostaje więc taka integracja kolejnych nowych doświadczeń, aby tworzyły one spójnie rozwijającą się całość. Aby zrealizować te cele, kluczowym wydaje się być zdefiniowanie samego pojęcia osobowość, czego autorzy ESOKJ (2003) nie robią.

1 Sformułowanie trening osobowościowy jest przez autorkę używane w odniesieniu do świadomych działań nauczyciela, mających na celu promowanie i monitorowanie określonych zachowań, utożsamionych z pewnymi celami osobowościowymi w celu ułatwienia komunikacji i kontaktów z innymi ludźmi, szczególnie tych realizowanych w języku obcym. 
Czynniki osobow ościowe w procesie przyswajania i użycia języka obcego...

\section{Zagadnienie osobowości w psychologii i psycholingwistyce}

Osobowość należy do terminów niezwykle trudnych do zdefiniowania, a jej postrzeganie zależy w dużej mierze od przyjętego stanowiska teoretycznego (Feist i Feist, 2006: 3). Termin osobowość, funkcjonuje również w języku potocznym, gdzie, pozbawiony naukowych fundamentów, rozumiany jest różnie przez przedstawicieli danej społeczności. Jak podkreślają Larsen i Buss (2005: 4), w życiu codziennym, intuicyjnie opisujemy osobowość innych, używając różnorakich przymiotników. W języku angielskim, na przykład, występuje ok. 20000 przymiotników osobowościowych (ang. trait descriptive adjectives). Fakt ten został zauważony nie tylko przez językoznawców, ale również przez psychologów i ma swoje odbicie w psychologicznych teoriach cech, zwanych również teoriami dyspozycyjnymi.

Jak zauważają Bernstein, Penner i Clarke-Stewart (2008), teorie cech zakładają, iż osobowość każdej jednostki składa się z unikatowej dla niej, uporządkowanej kombinacji względnie stałych cech. Cechy te przekładają się na pewne zgeneralizowane tendencje jednostki do określonych zachowań w różnych sytuacjach oraz warunkują przebieg interakcji międzyludzkich z udziałem tejże jednostki, a także jej adaptację w środowisku (Larsen i Buss, 2005: 4). Logicznym założeniem jest więc stwierdzenie, że mają one wpływ na przebieg komunikacji międzyludzkiej, również tej odbywającej się w języku obcym.

Gordon Allport (w Hall, Lindzey i Campbell, 2013: 31), psycholog amerykański uważany za twórcę psychologii osobowości, stwierdza, iż przypisując jednostce określone cechy jako zewnętrzni obserwatorzy, konstruujemy biospołeczny opis jej osobowości, który kontrastuje z jej biofizycznym ujęciem, w którym zakłada się, iż ludzka osobowość jest niemożliwa do pełnego zdefiniowania przez osoby zewnętrzne. Nauczyciele jako osoby nieposiadające pełnego wykształcenia psychologicznego i niewyposażone w różnego rodzaju narzędzia diagnostyczne, postrzegają osobowość ucznia właśnie z perspektywy biospołecznej. Również w kontekście edukacji językowej przypisują oni uczniom pewne cechy osobowości oraz, często podświadomie, zakładają, iż określone cechy pomagają lub też przeszkadzają w procesie opanowywania języka obcego. Badania pokazują, iż nauczyciele przejawiają w tym zakresie pewną zgodność i uważają, że uczeń osiągający sukcesy w nauce języków obcych jest ciekawy świata, wytrwały, zaangażowany, skrupulatny, zorganizowany, aktywny, elastyczny w kontaktach interpersonalnych, towarzyski, stanowczy, obdarzony wyobraźnią i niezależny (Lalonde, Lee i Gardner, 1987). Pokazują też, iż uwarunkowania osobowościowe mają realny wpływ na przebieg procesu opanowywania języka obcego. Wśród cech udowodnionych jako przydatne w tym procesie wymienia się m.in. otwartość, wysoką samoocenę i pewność 
siebie, gotow ość do podejmowania ryzyka czy też tolerancję niepewności (por. np. Biedroń, 2013; Studenska, 2011; Trawiński, 2005).

Jak dotąd, największą popularnością wśród badaczy zainteresowanych wpływem osobowości na procesy przyswajania języka obcego, cieszą się badania zgłębiające rolę cech ujętych w modelu tzw. Wielkiej Piątki. Jest on rezultatem długoletnich badań wielu psychologów, zaś za ostateczny przełom w jego kształcie odpowiedzialni są Lewis Goldberg, Robert M cCrae oraz Paul Costa. Zgodnie z nazwą, obejmuje on pięć wymiarów osobowościowych, tj.: (1) ekstrawersję, (2) ugodowość, (3) sumienność, (4) neurotyczność i (5) otwartość na doświadczenie (zob. Dörnyei, 2005). Jak pokazuje większość dotychczasowych badań, ekstrawertycy, mówiąc w języku obcym, charakteryzują się większą płynnością wypowiedzi, szczególnie w środowisku formalnym, jakim jest np. sala egzaminacyjna. Introwertycy zazwyczaj mówią wolniej, formułują krótsze wypowiedzi, częściej się wahają oraz robią więcej błędów (Dewaele i Furnham, 1999). Ponadto, jak podkreśla Dewaele (2012: 47), przewagę w klasie językowej mają jednostki o wysokim poziomie sumienności, ponieważ legitymują się cechami, które pozwalają im lepiej funkcjonować w środowisku edukacyjnym. Osoby sumienne lepiej zarządzają własnym czasem, charakteryzują się zdolnościami do myślenia analitycznego oraz wysokim poziomem chęci dążenia do celu (ang. achievement striving) (por. Studenska, 2011; Ockey, 2011). Jednakże, jak podkreśla Biedroń (2013: 7), to cecha otwartości na doświadczenie jest jednym z najważniejszych determinantów sukcesu w nauce języka obcego. Costa i M cCrae (1985) wskazują na korelacje między nią a inteligencją, natomiast Verhoeven i Vermeer (2002) łączą ją z różnorakimi umiejętnościami organizacyjnymi i pragmatycznymi.

Omawiając rolę czynników osobowościowych w procesie opanowywania języka obcego, należy podkreślić, że cechy osobowości nie tylko wpływają na siebie wzajemnie, ale również pozostają w skomplikowanej relacji z innymi cechami indywidualnymi jednostki, takimi jak jej wiek, inteligencja, zdolności językowe, style poznawcze, motywacja, nastawienie, czy też preferowane strategie uczenia się. Dla przykładu, amerykański psycholog, Jeffrey B. Braden (1995: 638), wskazuje na silne powiązanie między osobowością, a wytrwałością, kluczową dla procesów motywacyjnych. Badania prowadzone m.in. przez Fitzpatrick (2001), pokazują natomiast istnienie zależności pomiędzy osobowością jednostki, a jej nastawieniem do nauki języka, co z kolei ma wpływ na motywację.

Wspomniany wcześniej ESOKJ (2003: 97) wskazuje na cechy, które mogą mieć istotne znaczenie nie tyle w procesie opanowywania języka obcego, ile w procesie komunikacji w języku obcym. Są to, między innymi, rozmowność lub jej brak, poziom nieśmiałości, optymizmu, ekstrawersji, wstydliwości, umiejscowienie kontroli, elastyczność w kontaktach interpersonalnych, otwartość 
Czynniki osobow ościowe w procesie przyswajania i użycia języka obcego...

umysłu, spontaniczność, samokontrola, dokładność, pracowitość, ambicja, samoświadomość, zaufanie do samego siebie, pewność siebie, poczucie własnej wartości. Cechy te wchodzą w skład wspomnianej już osobowości interkulturowej, która charakteryzuje użytkowników języka obcego skutecznie podejmujących dialog z przedstawicielami innych kultur.

Podsumowując powyższe, trzeba podkreślić, iż osobowość jednostek ma wpływ zarówno na procesy związane z opanowywania języka obcego, jak również na przebieg aktów komunikacyjnych, niezależnie od faktu, czy mają one miejsce w kontekście formalnej edukacji językowej, czy też poza murami szkoły bądź uniwersytetu.

\section{Osobowość ucznia a ocena jego wypowiedzi ustnej}

Jako nauczyciel akademicki na Uniwersytecie Pedagogicznym im. KEN w Krakowie, autorka artykułu prowadzi zajęcia Discussion (pol. dyskusja, rozmowa) w ramach Praktycznej Nauki Języka Angielskiego dla studentów pierwszego roku anglistyki. Jednym z kryteriów oceny dla tego przedmiotu jest interaction (pol. interakcja), które w praktyce odnosi się do umiejętności prowadzenia rozmowy, odpowiedniego reagowania i pewnego rodzaju współpracy rozmów ców - w tym przypadku pary studentów. Działania i strategie interakcyjne są szczególnie istotne dla skutecznej komunikacji międzyludzkiej, ponieważ, jak twierdzi Field (2011), większość naturalnej komunikacji cechuje się koniecznością przekazywania i odbioru komunikatów między poszczególnymi uczestnikami rozmowy. Na wagę zadań interakcyjnych wskazuje się również w ESOKJ (2003: 73).

Wspomniani powyżej studenci filologii ćwiczą i są testowani w parach. Jak pokazują najnowsze badania, ten sposób pozwala uczniom lepiej zademonstrować swoje kompetencje interakcyjne niż tradycyjny model testowania przez nauczyciela czy egzaminatora (Taylor i Wigglesworth, 2009). Co istotne, jak udowodnili m.in. Berry (2007) czy Brown (2003), nie tylko asymetryczność relacji nauczyciel/egzaminator - uczeń/egzaminowany ma tutaj znaczenie. Ich badania wykazały, iż na jakość wypowiedzi wpływa też szereg innych czynników, takich jak wiek, płeć, poziom znajomości między rozmówcami, ich style prowadzenia rozmowy, czy też właśnie ich osobowości. Również według Kramsch (1986) na przebieg tej komunikacji mają wpływ dwa czynniki, tj. konwencje społeczne oraz właśnie czynniki osobowościowe rozmówców.

W ciągu trzech lat prowadzenia zajęć Discussion², autorka zauważyła, iż niektórzy, często bardzo dobrzy językowo studenci, miewają na egzaminie problemy, które, jak wynika z obserwacji, mogą być rezultatem ich uwarunkowań

${ }^{2}$ Co wiązało się również z przeprowadzaniem końcowych egzaminów ustnych. 
osobowościowych, a nie braków językowych. Niektórym zdarza się na przykład zupełnie dominować rozmowę, nie dopuszczać partnera do głosu, inni zaś mają problem z przejęciem inicjatywy. Gdy podczas ćwiczeń zostają przypisani do dominującego partnera, są wręcz zadowoleni, że nie muszą się odzywać. Jak pokazuje praktyka, rozwiązanie tego problemu jest bardzo proste i wiąże się z przekazaniem studentom jasnego komunikatu, np. „Ponieważ prowadzicie rozmowę, interesuję mnie zdanie obu osób. Zarówno dominacja rozmowy, jak i unikanie odpowiedzi wpływa negatywnie na waszą ocenę". W przeważającej większości przypadków, taki komunikat przynosi efekty i studenci pilnują się wzajemnie, tak aby zachować równowagę w rozmowie. Co więcej, często opracowują sobie w tym celu specjalny system znaków. Sytuacja ta, choć nienaturalna, zdaje się pokazywać, iż jesteśmy w stanie kontrolować swoje wrodzone uwarunkowanie osobowościowe np. dominację czy nieśmiałość, jeśli wiemy, iż przyniesie nam to korzyści, tutaj w postaci pozytywnej czy wyższej oceny. Spostrzeżenia te zdają się być zgodne z teorią cech wolnych i kluczowych projektów osobistych, zaproponowaną przez psychologa Briana Little, którą opisał w książce Me, myself and us (2004).

Według Little’a (2004), pomimo z gruntu stałej natury naszej osobowości, zdarza nam się zachowywać niezgodnie z naszymi cechami. Mówimy wtedy o aktywacji tzw. cech wolnych (ang. free traits), które manifestują się w zachowaniach chwilowych, pozostających w sprzeczności lub konflikcie z naszą naturą. Aktywacja cech wolnych ma miejsce, gdy na szali ważą się kluczowe dla nas projekty osobiste, innymi słowy, gdy zagrożona jest realizacja lub trwałość rzeczy dla nas ważnych, zarówno w życiu zawodowym, jak i prywatnym. Jak wspomina Little (2016), nieśmiała, małomówna i pokojowo nastawiona mama może zachować się agresywnie, głośno i nachalnie w przypadku, gdy z chorym dzieckiem jest ignorowana przez personel szpitalny. Dla studenta studiów filologicznych kluczowym projektem może być ich ukończenie, co wiąże się z uzyskaniem pozytywnych wyników egzaminów. Wydaje się więc, że może on być on gotowy na pewne reakcje, czasami sprzeczne z jego uwarunkowaniami osobowościowymi, ponieważ jest świadomy, iż modyfikacje we własnym zachowaniu pomogą mu w osiągnięciu nadrzędnego celu.

\section{5. Świadome kontrolowanie zachowań wynikających z uwarunkowań osobowościowych a ocena egzaminu ustnego - ankieta studencka}

W związku z powyższym, autorka założyła, iż studenci zdający egzamin formalny, w języku obcym, świadomie modyfikują swoje zachowanie, często wbrew swoim wrodzonym cechom osobowości, aby uzyskać lepszą ocenę. W celu zweryfikowania tej hipotezy przeprowadzono ankietę wśród 54 studentów trzeciego 
Czynniki osobowościowe w procesie przyswajania i użycia języka obcego...

roku filologii angielskiej studiów dziennych Uniwersytetu Pedagogicznego im. KEN w Krakowie, którzy mają już za sobą, co najmniej trzy formalne, ustne egzaminy w języku obcym, tj. egzamin maturalny oraz zdawane w parach egzaminy ustne na zakończenie pierwszego i drugiego roku studiów. Internetowa ankieta składała się z pytań otwartych i zamkniętych, a jej wypełnienie było anonimowe i dobrowolne.

Pytanie pierwsze dotyczyło kwestii podejmowania podczas egzaminów ustnych świadomych, sprzecznych z własną osobowością zmian we własnym zachowaniu (dokładne brzmienie pytania oraz odpowiedzi udzielone przez studentów ilustruje Wykres 1).

Czy podczas egzaminów ustnych w języku obcym zdarza Ci się świadomie zachowywać sprzecznie ze swoją osobowością? (np. starasz się mówić więcej/mniej niż masz w zwyczaju)

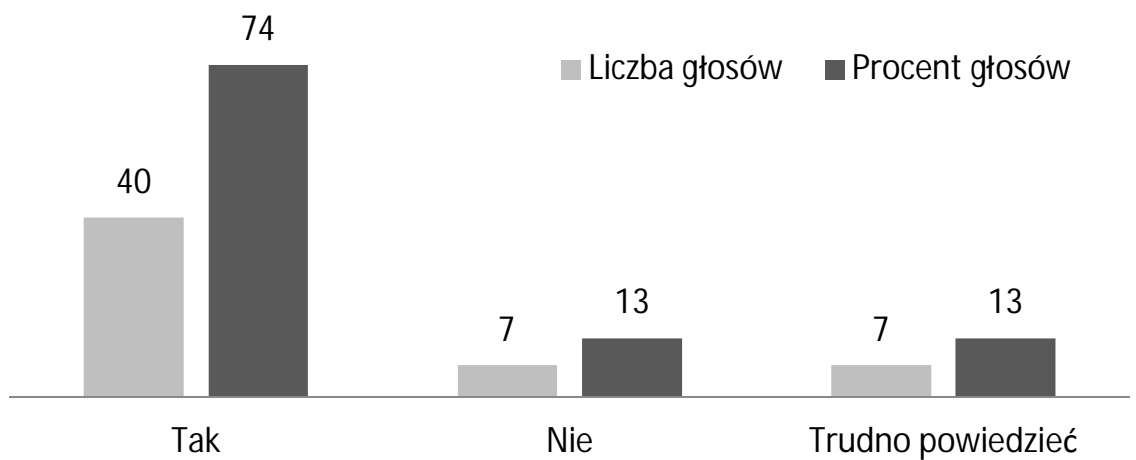

Wykres 1: Liczba odpowiedzi i ich procentowy udział dla poszczególnych wyborów w pytaniu nr 1.

Pytanie drugie skierowane było tylko do osób, które w pytaniu pierwszym odpowiedziały "tak" i dotyczyło powodów takich zmian w zachowaniu. Łącznie 40 studentów dokonało 102 wskazań. 14 osób pominęło to pytanie (zgodnie z zaleceniem). 22 osoby jako powód zmian w swoim zachowaniu wskazały chęć lepszego zaprezentowania się przed egzaminatorami. 13 ankietowanych wskazało na chęć pomocy rozmówcy, po 20 osób wybrało opcję „chcę kontrolować swoje zachowanie i przez to wpłynąć na poziom mojej wypowiedzi" oraz "chcę kontrolować swoje zachowanie i przez to wpłynąć na ocenę mojej wypowiedzi przez egzaminatorów". 7 osób wymieniło też inne pow ody. 5 badanych wskazało na zmiany zachowania spowodowane stresem, co wyklucza ich celow ość i intencjonalność. Kolejne 2 osoby również wymieniły czynniki leżące poza ich kontrolą: jedna wskazała na potrzebę/konieczność (a nie "chęć pomocy" jak w opcji numer 2) dostosowania się do rozmówcy, natomiast druga źródeł zmian w swoim zachowaniu upatrywała w formie samego egzaminu. 
Pytanie trzecie miało na celu sprawdzenie, jakie modyfikacje we własnym zachowaniu, w sposób świadomy, podejmują studenci. Miało ono następującą treść:

Czy podczas egzaminu ustnego z języka obcego zdarza Ci się świadomie starać się być bardziej/mniej ............. niż leży to w twojej naturze/osobowości.

W wykropkowanym miejscu pojawiły się przetłumaczone na język polski przymiotniki osobowościowe (lub odpowiadające im dłuższe opisy) z listy zaproponowanej przez amerykańskiego psychologa Normana Andersona (1968). Dodatkow o pojawiła się również opcja „żadne z powyższych” (0 wskazań) oraz „nie podejmuję świadomych prób zmian w swoim zachowaniu podczas egzaminów ustnych w języku obcym" (1 wskazanie). Szczegółowy rozkład odpowiedzi widoczny jest w Tabeli $\mathrm{nr} 1$.

\begin{tabular}{|c|c|c|}
\hline WARIANT ODPOWIEDZI & \begin{tabular}{|c|} 
UDZIAt \\
PROCENTOWY
\end{tabular} & $\begin{array}{c}\text { LICZBA } \\
\text { GŁOSÓW }\end{array}$ \\
\hline Być bardziej poważnym niż leży to w twojej naturze/ osobowości & \begin{tabular}{|l|}
$43 \%$ \\
\end{tabular} & 23 \\
\hline Być mniej poważnym niż leży to w twojej naturze/ osobow ości & $4 \%$ & 2 \\
\hline Być bardziej rozmownym niż leży to w twojej naturze/ osobowości & $52 \%$ & 28 \\
\hline Być mniej rozmownym niż leży to w twojej naturze/ osobowości & $11 \%$ & 6 \\
\hline Być bardziej wyrozumiałym dla swojego rozmówcy niż leży to w twojej naturze/ osobowości & $31 \%$ & 17 \\
\hline Być mniej wyrozumiałym dla swojego rozmówcy niż leży to w twojej naturze/osobowości & $2 \%$ & 1 \\
\hline Być bardziej kłótliwym niż leży to w twojej naturze/osobowości & $17 \%$ & 9 \\
\hline Być bardziej ugodowym niż leży to w twojej naturze/osobowości & $35 \%$ & 19 \\
\hline Być bardziej aktywnym niż leży to w twojej naturze/ osobowości & $56 \%$ & 30 \\
\hline Być mniej aktywnym niż leży to w twojej naturze/osobowości & $9 \%$ & 5 \\
\hline Być bardziej skupionym niż leży to w twojej naturze/ osobowości & $35 \%$ & 19 \\
\hline Być bardziej odważnym niż leży to w twojej naturze/osobowości & $24 \%$ & 13 \\
\hline Być mniej odważnym niż leży to w twojej naturze/osobowości & $13 \%$ & 7 \\
\hline Być bardziej opanowanym niż leży to w twojej naturze/osobow ości & $17 \%$ & 9 \\
\hline Być bardziej ciekawym opinii rozmówcy niż leży to w twojej naturze/osobowości & $31 \%$ & 17 \\
\hline Być bardziej cynicznym niż leży to w twojej naturze/osobowości & $2 \%$ & 1 \\
\hline Być mniej cynicznym niż leży to w twojej naturze/ osobow ości & $22 \%$ & 12 \\
\hline Być bardziej bezpośrednim niż leży to w twojej naturze/ osobowości & $9 \%$ & 5 \\
\hline Być mniej bezpośrednim niż leży to w twojej naturze/ osobowości & $19 \%$ & 10 \\
\hline Być bardziej egoistycznym niż leży to w twojej naturze/ osobowości & $11 \%$ & 6 \\
\hline Być mniej egoistycznym niż leży to w twojej naturze/osobowości & $7 \%$ & 4 \\
\hline Być bardziej szczerym niż leży to w twojej naturze/ osobowości & $13 \%$ & 7 \\
\hline Być mniej szczerym niż leży to w twojej naturze/osobowości & $30 \%$ & 16 \\
\hline Być bardziej pomocnym niż leży to w twojej naturze/ osobow ości & $20 \%$ & 11 \\
\hline Być mniej pomocnym niż leży to w twojej naturze/ osobowości & $0 \%$ & 0 \\
\hline Być bardziej dowcipnym niż leży to w twojej naturze/osobowości & $4 \%$ & 2 \\
\hline Być mniej dowcipnym niż leży to w twojej naturze/osobowości & $26 \%$ & 14 \\
\hline Być bardziej dociekliwym niż leży to w twojej naturze/osobowości & $31 \%$ & 17 \\
\hline Być mniej dociekliwym niż leży to w twojej naturze/osobowości & $7 \%$ & 4 \\
\hline Być skromniejszym niż leży to w twojej naturze/osobowości & $9 \%$ & 5 \\
\hline Być bardziej cierpliwym niż leży to w twojej naturze/osobow ości & $24 \%$ & 13 \\
\hline Być bardziej uprzejmym niż leży to w twojej naturze/osobowości/c & $13 \%$ & 7 \\
\hline
\end{tabular}


Czynniki osobowościowe w procesie przyswajania i użycia języka obcego...

\begin{tabular}{|l|c|c|}
\hline Być bardziej tolerancyjnym niż leży to w twojej naturze/ osobowości & $20 \%$ & 11 \\
\hline Być mniej tolerancyjnym niż leży to w twojej naturze/ osobowości & $0 \%$ & 0 \\
\hline Być chętniejszym do współpracy niż leży to w twojej naturze/ osobowości & $28 \%$ & 15 \\
\hline Być bardziej ekstrawertycznym niż leży to w twojej naturze/osobowości & $30 \%$ & 16 \\
\hline Być bardziej introwertycznym niż leży to w twojej naturze/ osobow ości & $9 \%$ & 5 \\
\hline Żadne z powyższych & $0 \%$ & 0 \\
\hline $\begin{array}{l}\text { Nie podejmuję świadomych prób zmian w swoim zachowaniu podczas egzami- } \\
\text { nów ustnych w jezzyku obcym }\end{array}$ & $2 \%$ & 1 \\
\hline
\end{tabular}

Tabela 1: Liczba odpowiedzi i ich procentowy udział dla poszczególnych wyborów w pytaniu $\mathrm{nr} 3$.

W pytaniu numer cztery studenci mieli okazję wskazać na inne zmiany we własnym zachowaniu, nieujęte we wcześniejszym pytaniu. Dwie osoby wskazały na nieszczerość, do której się uciekły, w celu dojścia do porozumienia zrozmówcą lub podtrzymania rozmowy. Ostatnie pytanie (numer pięć) brzmiało:

Czy uważasz, że zmiany w zachowaniu, jakie wymieniono w pytaniach $3 \mathrm{i} /$ lub 4 , mog $q$ byćpomocnew uzyskaniu lepszego wyniku z egzaminu ustnego w języku obcym? 40 osób (74\% ankietowanych) odpowiedziało twierdząco, 2 osoby (4\%) przecząco, natomiast 12 osób (22\%) zaznaczyło opcję "trudno powiedzieć".

Na podstawie zebranych danych można wysnuć szereg wniosków, z których najważniejsze dla poruszonych w niniejszym artykule zagadnień przedstawiono poniżej.

1) Większość studentów (74\%) otwarcie deklaruje, iż podczas egzaminów ustnych świadomie podejmuje zachowania niezgodne ze swoimi uwarunkowaniami osobowościowymi ${ }^{3}$.

2) Taki sam procent badanych uważa, że zmiany te mogą mieć wpływ na uzyskanie lepszej oceny z egzaminu ustnego. 20 studentów uważa, że poprzez kontrolę swojego zachowania realnie wpływa na poziom swojej wypowiedzi; taka sama liczba uważa zaś, że może wpłynąć na odbiór tejże wypowiedzi przez egzaminatorów. Ponadto, 41\% ankietowanych studentów chce poprzez zmiany w swoim zachowaniu zaprezentować się lepiej jako osoba przed egzaminatorami (duża popularność tej opcji może świadczyć o przekonaniu studentów co do możliwości pewnego „zmanipulowania” swoich słuchaczy, w celu wzbudzenia sympatii czy ukrycia braków językowych).

3) Egzamin ustny wywołuje w studentach, przede wszystkim, potrzebę zwiększenia swojej aktywności (56\% ankietowanych), skupienia (35\%) i powagi (43\%). Podniesiony poziom aktywności i skupienia może się wiązać z chęcią

${ }^{3}$ Jak pokazało pytanie numer trzy, gdzie wymienione są konkretne przykłady takich zachowań, procent ten jest jeszcze większy - tylko jedna osoba wybrała tutaj opcję „nie podejmują świadomych prób zmian w swoim zachowaniu (...)”. 
i/lub koniecznością zaprezentowania własnych umiejętności językowych w krótkim czasie, poczucie potrzeby zachowania powagi wskazuje zaś na sposób, w jaki studenci odbierają charakter takich egzaminów.

4) Studenci są gotowi do zmiany własnych zachowań ze względu na swojego rozmówcę - deklarują, iż stają się oni bardziej rozmowni (50\% ankietowanych), ugodowi (33\%), wyrozumiali (31\%) oraz ciekawi jego opinii (31\%). Wydaje się jednak, że zmiany te postrzegają w większości jako korzystne dla siebie, ponieważ jedynie 13 ankietowanych jako powód modyfikacji w swoim zachowaniu podało chęć udzielenia pomocy swojemu rozmówcy.

5) Zebrane dane mogą jedno cześnie sugero wać, że cechy osobowości najczęściej wskazywane przez ankietowanych studentów ułatwiają komunikację w języku obcym, a to z kolei znajduje odzwierciedlenie w ocenie wypowiedzi ustnej; zachowania utożsamiane ztymi cechami powinny być więc promowane wśród uczniów i użytkowników języków obcych.

\section{Podsumowanie}

Przeprowadzona ankieta pokazała, iż w sytuacjach egzaminacyjnych rola czynników osobowościowych nie jest bez znaczenia. Ich wpływ zarówno na przebieg, jak i rezultat egzaminów ustnych dostrzegają doświadczeni i odnoszący sukcesy w nauce języka obcego studenci filologii angielskiej. W konsekwencji, świadomie modyfikują swoje zachowania tak, żeby sprawić dobre wrażenie, lepiej dopasować się do swojego rozmówcy, czy też wpłynąć na ocenę egzaminatorów.

Zarówno z przytoczonych danych empirycznych, jak i z przedstawionych w artykule koncepcji teoretycznych, jasno wynika, iż warto promować wśród uczniów i studentów pewne zachowania utożsamiane zokreślonymi cechami osobowości. Ponieważ proces nauczania języka obcego ma przygotowywać ucznia do skutecznej komunikacji w tym języku z przedstawicielami różnych kultur, należałoby założyć, że kształtowanie zachowań, czy też cech osobowości utożsamianych na przykład ze wspomnianą osobowością interkulturową, powinno znaleźć odzwierciedlenie w zakładanych efektach kształcenia, gdyż w konsekwencji oznaczałoby to możliwość ich oceniania. W praktyce zaś mogłoby zadziałać jako czynnik motywacyjny, zachęcający uczniów do zwiększonej gotowości, do kontroli lub aktywacji swoich zachowań w zależności od kontekstu, co wiązałoby się z koniecznością pracy pracą nad rozwojem własnej osobowości.

\section{BIBLIOGRAFIA}

Anderson N. H. (1968), Likableness ratings of 555 personality-trait words (w) „Journal of Personality and Social Psychology", nr 9 (3), str. 272-279. 
Czynniki osobow ościowe w procesie przyswajania i użycia języka obcego...

Bernstein D. A., Penner L. A., Clarke-Stewart A., Roy E. (2008), Psychology. Boston, MA: Houghton M ifflin Company.

Berry V. (2007), Personality differences and oral test performance. Frankfurt: Peter Lang. Biedroń A. (2011), Personality factors as predictors of foreign language aptitude (w) „Studies in Second Language Learning and Teaching", nr 1 (4), str. 467-489.

Biedron A. (2013), Stability and variability of gifted $L 2$ learners' personality within a Dynamic Systems Theory paradigm (w) Piechurska-Kuciel E., Piasecka L. (red.), Variability and stability in foreign and second language learning contexts. Newcastle upon Tyne: Cambridge Scholars Publishing, str. 2-26.

Braden J. P. (1995), Intelligence and personality in school and educational psychology (w) Saklofske D.H., Zeidner M . (red.), International handbook of personality and intelligence. New York, London: Springer, str. 621-650.

Brown A. (2003), Interviewer variation and the co-construction of speaking proficiency (w) „Language Testing”, nr 20(1), str. 1-25.

Costa P. T., M cCrae R. (1985), The NEO personality inventory: Manual form S and form R. Odessa, Florida: Psychological Assessment Resources.

Dewaele J. (2012), Personality: Personality traits as independent and dependent variables (w) Mercer S., Ryan S., Williams M. (red.), Psychology for language learning: insights from research, theory and practice. Basingstoke: Palgrave M acmillan, str. 42-57.

Dewaele J., Furnham A. (1999), Extraversion: The unloved variable in applied linguistic research (w) „Language Learning”, nr 49 (3), str. 509-544.

DiSalvo D. (2018), Can Personality Change or Does It Stay the Same for Life? A New Study Suggests It's a Little of Both (w) "Forbes" Online: https:// www.forbes.com/sites/daviddisalvo/2018/08/20/can-personality-chan ge-or-it-stay-the-same-for-life-a-new-study-says-its-a-little-of-both/\#3 25cc31279ca [DW 05.08.2018].

Dörnyei Z. (2005), The psychology of the language learner: Individual differences in second language acquisition. London: Lawrence Erlbaum Associates, Publishers.

Feist J., Feist G.J. (2006), Theories of personality. Boston: M cGraw-Hill.

Field J. (2011), Cognitive validity (w) Taylor L. (red.), Examining speaking: research and practice in assessing second language speaking. Cambridge: University of Cambridge ESOL Examinations/Cambridge University Press, str. 65-111. Fitzpatrick P. (2001), A parent's guide to bilingualism. Norderstedt: Books on Demand $\mathrm{GmbH}$.

Fontana D. (1991), Psychology for teachers. Leicester: British Psychology Society. Furnham A., Chamorro-Premuzic T. (2004), Personality and intelligence as predictors of statistics examination grades (w) „Personality and Individual Differences", nr 37, str. 943-955. 
Hall C. S., Lindzey G., Campbell J. B. (2013), Teorie osobowości. Warszawa: Wydawnictwo Naukowe PWN.

Kramsch C. (1986), Interactive discourse in small and large groups (w) Rivers

W. (red.), Interactive language teaching. Cambridge: Cambridge University Press, str. 17-29.

Lalonde R. N., Lee P. A., Gardner R. C. (1987), The common view of the good language learner: An investigation of teachers' beliefs (w) "The Canadian M odern Language Review", nr 44, str. 16-34.

Larsen R. J., Buss D. M. (2005), Personality psychology: Domains of knowledge about human nature. New York: McGraw Hill.

Liang H. Y., Kelsen B. (2018), Influence of Personality and M otivation on Oral Presentation Performance (w) "Journal of Psycholinguist Research", nr 47 (4), str. 755-776.

Little B. (2014), My, myself and I: The science of personality and the art of wellbeing. New York: Public Affairs.

O'Brian P. G., Kennedy W. Z, Ballard K. A. (2007), Psychiatric. M ental health. Nursing. An introduction to theory and practice. Burlington: Jones \& Bartlett Publishing. Ockey G. (2011), Self-consciousness and assertiveness as explanatory variables of L2 oral ability: A latent variable approach (w) „Language Learning", nr 61(3), str. 968-989.

Rada Europy (2003), Europejski system opisu kształcenia językowego: uczenie się, nauczanie, ocenianie. Warszawa: Wydawnictwo CODN.

Trawiński M. (2005), An outline of second language acquisition theories. Kraków: Wydawnictwo Naukowe Akademii Pedagogicznej.

Studenska A. (2011), Personality and parenting styles as predictors of self-regulation in foreign language learning (w) Arabski J., Wojtaszek $A$. (red.), Individual learner differences in SLA. Bristol, Buffalo, Toronto: Multilingual Matters, str. 44-62.

Taylor L., Wigglesworth G. (2009), Are two heads better than one? Pair work in

12 assessment contexts (w) "Language Testing," nr 26 (3), str. 325-339.

Verhoeven L., Vermeer A. (2002), Communicative competence and personality dimensions in first and second language learners (w) „Applied Psycholinguistics", nr 23 (3), str. 361-374.

\section{NETOGRAFIA}

Little B. (2016). Who are you, really? The puzzle of personality [TED talk]. https:// www.ted.com/talks/brian_little_who_are_you_really_the_puzzle_of_pe rsonality [DW 12.05.2018] 